\title{
Research on the Reform of Physical Education Teaching and Quality Education in Colleges and Universities
}

\author{
Han Xu \\ Beijing Printing Institute, Beijing 102600
}

Keywords: College physical education; liberal education; teaching reform

\begin{abstract}
Starting from the main content of liberal education, this paper analyzes the problems existing in current physical education teaching in colleges and universities, such as backward teaching concepts, insufficient teachers' enthusiasm and low teachers' quality. Then, this paper combines the guiding content in liberal education. and probes into the corresponding countermeasures for the reform of physical education in colleges and universities.
\end{abstract}

Liberal education is an important guiding ideology in promoting the development of education in our country. Under the background of continuous development of social economy, how to train compound talents with innovative consciousness has become an important research topic in the reform of physical education in colleges and universities in China.

\section{Analysis of the connotation of quality education}

With the continuous popularization of higher education in China, the reform of college physical education has gradually aroused widespread concern of the community. The implementation of the liberal education and the improvement of the quality of physical education have become the needs of the people and the country. As the foundation of the educational activities in China, the liberal education has been highly valued by the liberal education since it was put forward, and has gradually been promoted throughout the country. Quality education is different from traditional education. The traditional educational concepts lay particular emphasis on the teaching of skills and theories, while the liberal education places more emphasis on the cultivation of ideology, ability, personality and physical and mental health.[1]Quality Education and traditional education are corresponding, but they are not opposite relations. With the continuous deepening of the liberal education, the guiding role of liberal education in teaching activities has been gradually verified, laying a theoretical foundation for the training of all-round development-oriented talents. Therefore, the liberal education will also provide effective theoretical reference and ideological support for the reform of college physical education. 


\section{The dilemma faced by college physical education reform.}

\subsection{The concept of education is backward}

Since the popularization of liberal education, all colleges and universities in China have conducted research on quality education, but due to the influence of many objective factors, the practical effect of liberal education in college physical education is not ideal. On the face of it, the reform of physical education in colleges and universities is lack of innovation, but its essence is a reflection of the lack of thorough understanding of liberal education. The main reason for this problem is that physical education in colleges and universities has not carried out the teaching concept of "student-oriented", and put the management of students in a higher position than the development of students. The idea of liberal education has remained on the teaching documents. Therefore, the reform of physical education in colleges and universities must adhere to the principle of "student-oriented" development, grasp the key points of the reform of physical education in colleges and universities. ${ }^{[2]}$ At present, college students lack of interest and motivation in physical education, and their learning process is disorganized and unplanned. The reform of physical education in colleges and universities focuses on stimulating students' interest in learning, enriching the content of physical education with diversified teaching methods, and thus improving the quality of physical education.

\subsection{Teacher's motivation is insufficient.}

In 1999, the Ministry of Education of the People's Republic of China issued guidelines on quality-oriented education, stating that "actively promoting liberal education is a major task ahead of us without delay."By now, the implementation of the liberal education has experienced a long time,"quality education, teaching reform" has become a platitude. However, the physical education teaching concept of college physical education teachers has not developed with the change of time. In the practice of quality education, there is lack of enthusiasm and enthusiasm. The focus of work is more on the teaching of skills and knowledge. Some teachers in colleges and universities believe that as long as the teaching task can be completed, they can ensure the quality of physical education and there is no need for the reform of physical education. This leads to the fact that college physical education activities are still in the same league and cannot stimulate students' enthusiasm for learning ${ }^{[3]}$ From a macro point of view, there must be loopholes in the management mechanism of higher education in our country, which will lead to the problem of teachers' attitude to teaching reform. This not only is disadvantageous to the university sports teaching reform the development, also has caused certain barrier to the university student's comprehensive development. ${ }^{[4]}$

\subsection{Teachers' quality is on the low side.}

As a practitioner and guide in the reform of physical education, front-line physical teachers play a vital role in the reform of physical education activities in colleges and universities. However, the current practical thinking and practical ability of college physical education teachers are obviously insufficient. In the course of the reform, the teaching reform is only regarded as a task, and there is no consciousness to improve the quality of education. Looking over the teaching situation of physical education in colleges and universities in China, it is not difficult to find that quite a number of teachers are short of professional knowledge. In the process of teaching reform, the work ideas are not clear, and there is no targeted reform method. In the process of teaching, "instillation" is still adopted.--Passively accepting the "style" teaching method, teaching behavior, language is not interesting, pertinent, resulting in students have a certain resistance to the physical education 
curriculum.

3. The strategy of college physical education reform from the perspective of quality education.

\subsection{Change teaching concept}

The main purpose of higher education is to inherit culture and train talents. Since the reform and opening up, China's per capita education has been significantly improved, and higher education has played an important role in China's economic development. At present, the pressure of employment is becoming more and more great, and the social economy has entered a new stage of development. This requires universities to play their own educational intelligence and advanced cultural role to provide a boost to China's social development. The pace of college sports reform is accelerating with the continuous development of colleges and universities. The role and position of quality education in college physical education is becoming more and more clear. However, the teaching concepts of most front line teaching workers have not been updated, and the teaching level is also upgrading.[5] Therefore, in this case, the university sports teaching must conform to the national development demand, unifies the university development direction to carry on the design plan, starts from the university sports teaching infrastructure, the curriculum plan, and enhances the university sports teaching quality earnestly. From the perspective of quality education, college physical education should focus on cultivating students' learning behavior and comprehensive quality. The goal of teaching activities should be long-term, so as to deepen the teaching concept and educational goals of college physical education teachers. Specific colleges and universities should regularly teach and train physical education teachers in colleges and universities, so that physical education teachers can absorb new teaching concepts in the process of training and continuously improve their professional level. In addition, colleges and universities can also carry out open class competitions on a regular basis, so that college physical education teachers can continuously innovate teaching models in competitions, and put various theories in quality education into practice, so as to enhance the emphasis of college physical education teachers on teaching reform.

\subsection{Reform and innovation practice}

Under the complicated social and educational background, the way out of the reform of physical education in colleges and universities lies in "innovation in practice" Its essence refers to the high-quality talents who have strong knowledge base and thinking ability, at the same time these talents also need to have good ideological quality and ability to solve complex problems. Aiming at the cultivation of innovative talents, there have been a lot of teaching examples at home and abroad. In this process, the guiding ideology of quality education plays a key role. Therefore, physical education in colleges and universities should be innovated and improved on the basis of the guiding ideology of liberal education. To this end, colleges and universities should improve the liberal education in the application of various educational theories in college physical education, through the reliable teaching theory to create a good teaching atmosphere. A liberal education approach to physical education and its system.[6]For example, in the process of teaching, physical teachers in colleges and universities can as far as possible adopt the results of physical teaching research, timely replacement of outdated teaching content, appropriate increase to stimulate students' interest in learning sports projects. For example, rock climbing, sports dance and other projects, to enrich the university sports teaching resources, stimulate the enthusiasm of college students. 


\subsection{Personalized teaching}

Quality Education not only means that physical education in colleges and universities should change the traditional teaching mode of "inculcation-passive acceptance", but also means that physical education in colleges and universities should pay attention to students' independent and cooperative learning and emphasize the guidance of students' learning methods teaching through students' independent thinking. But, because of the difference of family environment, study foundation, study habit, the student's study level has certain difference. This shows that the unified teaching model can not make all students' learning level can be effectively improved. In this regard, teachers should reflect the "student-oriented" teaching principles according to the actual learning situation of students, establish a teaching system for students at different levels, and emphasize the individualized development of students so that all students can be in the teaching activities."Learn to have income."For example, can test students at the beginning of their enrollment, and then divide students into different teaching groups according to physical fitness tests and interest tests. In the process of teaching, differentiated teaching can be carried out, so that all students can improve in college physical education. However, the division of the hierarchy in the differentiated teaching needs to follow the principle of "dynamicization. Teachers need to regularly test the students and then rationally adjust the learning group where the students are located.

In addition, physical teaching in colleges and universities from the perspective of liberal education should pay close attention to the key link of curriculum planning. First of all, in the curriculum should reflect the characteristics of physical education content, combined with the students' professional, reasonable expansion of physical education professional caliber, emphasizing the promotion of students' basic academic ability. Secondly, the curriculum should reflect the practicality and the times. College physical education teachers should pay close attention to the status of social development and development needs. The content of the curriculum should be able to connect with the society. Finally, in terms of teaching methods, college physical education teachers should carry out new technologies and methods thorough analysis, timely replacement of old methods, and constantly improve the inadequacies of college physical education in the process of practice. In order to continuously improve the effectiveness and quality of college physical education.

\section{Conclusion}

To sum up, physical education, as an important part of higher education in our country, must carry out the guiding content in the liberal education against the background of the continuous implementation of the liberal education. Only by combining the quality development of physical education in colleges and universities with the guiding ideology of liberal education and the teaching practice with the theory of liberal education, can we train the innovative talents needed by the present society.

\section{References}

[1] Zhang Qing, Xiong Runjie. The Choice of Innovation Path of University Physical Education Based on Quality Education [J]. Aurora Borealis, 2016(2): 275-276.

[2] Wu Meng. On the Implementation of Quality Education in College Physical Education [J]. West Quality Education, 2016(20): 36-36.

[3] Huang Xiuquan. Discussion on Quality Education and Reform of Physical Education Curriculum in Colleges and Universities [J]. Sports Fashion, 2017.

[4] Lian Yang. Research on the Practice Path of College Physical Education Reform from the Perspective of Quality Education [J]. Heilongjiang Higher Education Research, 2016(6). 
[5] Feng Wenjie. Discussion on the Implementation of Quality Education in Physical Education Teaching in Colleges and Universities [J]. Journal of Chifeng University (Natural Science), 2017(13).

[6] Wu Anjun, Berlin. Research on the Practice of Public Physical Education in Colleges and Universities from the Perspective of Quality Education [J]. Journal of Social Sciences, Jiamusi University, 2016(5): 194-195. 